\title{
UJI DAYA HASIL UBIKAYU (Manihot esculenta Crantz) VARIETAS UJ5 PADA BERBAGAI UMUR PANEN
}

\author{
Palupi Puspitorini ${ }^{1}$ ) Dyah Pitaloka ${ }^{2}$ ), Tri Kurniastuti ${ }^{1)}$ \\ 1) Program Studi Agroteknologi Unisba Blitar \\ 2) Program Studi Agroteknologi Universitas Raden Rahmad Malang
}

This study aims to find out the results of cassava tuber crop UJ5 variety at different harvest ages. Research direction is that cassava varieties have been planted throughout Indonesia as the best producer of cassava varieties. High levels of starch and high HCN content makes this variety was selected by the factory - tapioca factory in Indonesia. Research design used randomized block design with 7 treatments of harvesting (UP) were repeated 3 times. UP6 (harvesting 6 MAP), UP7 (harvesting 7 MAP), UP8 (harvesting 8 MAP), UP9 (harvesting 9 MAP), UP10 (harvesting 10 MAP), UP11 (harvesting 11 MAP), UP12 ( harvesting 12 MAP). The research variables are the fresh weight of tuber, tuber starch content (\%), the weight of biomass, harvest index, number of tubers per plant. The results showed that the best harvesting time is UP9 the results did not differ with UP10, UP11 and UP12

Keyword : cassava yield, plant harvests ages

\section{PENDAHULUAN}

Produksi nasional sebesar 89,47\% merupakan kontribusi tujuh provinsi utama penghasil ubikayuyaitu Jawa Timur, Jawa Tengah, Lampung, Sumatera Selatan, SulawesiTenggara,Maluku, danYogyakarta, sedangkan produksi provinsi lainnya sekitar 11-12\% (Prihandana et al., 2007).

Ubikayu di Indonesia selain sebagai makanan pokok masyarakt sehari hari juga sangat mudah ditumbuhkan. Ubikayu digunakan sebagai pakan ternak, bahan baku industri tapioka atau pati, bahan baku bioethanol atau biopremium. Nilai ekonomi ubikayu dinilai penting dibandingkan dengan umbiumbi lainnya. Jenis ini kaya akan karbohidrat dan merupakan makanan pokok di daerah tandus di Indonesia. Selain umbinya, Produk olahan dari bahan singkong dapat ditemukan di beberapa tempat diantaranya di Blitar, Malang Jawa Timur, DI Yogyakarta, Wonogiri, Temanggung. Berbagai macam produknya antara lain, krupuk, tiwul instan, kripik, krupuk, kue-kue, bidaran, gatot dan lainlain.

Banyak sekali varietas unggul yang telah dirilis pemerintah baik unggul sebagai ubikayu untuk bahan makanan pokok maupun sebagai bahan baku industri tapioka. Sebagai bahan baku tapioka dipilih ubikayu yang kandungan HCN dan kadar pati (starch content) tinggi. Di era sebelum tahun 2000 varietas unggul

yang digunakan sebagai bahan baku tapioka mayoritas adalah Adira4. Saat ini mayoritas kebun ubikayu untuk bahan baku tapioka beralih ke varietas UJ5 yang mempunyai hasil (starch production) lebih tinggi.

Badan Penelitian Tanaman Ubi dan Kacan-kacangan (Balitkabi) telah mengeluarkan varietas ubikayu dalam upaya merespon kebutuhan petani. Akan tetapi klon-klon yang belum dilepas perlu 
dilakukan pengujian terlebih dahuluuntuk mendapatkan klon yang unggul(Balitkabi). Sementara peneliti lain diluar peneliti Balitkabi hanya sedikitmenghasilkanvarietas ubikayu. Dari jumlah yang sedikit tersebut, varietas ubikAyu yang dihasilkan di luar Balitkabi antara lain UJ-3, UJ-5, dan terakhir Mulyoyang belum dilepas secara resmi oleh pemerintah (Sudjadi, 2008).

Industri tapioka di Indonesia yang semakin berkembang baik dan keberpihakan pemerintah dalam memacu industri bioethanol sebagai penyangga kebutuhan premium nasional yang merupakan sumber energi terbarukan patut didukung dengan adanya penelitian-penelitian yang berorientasi pada peningkatan hasil ubikayu dan efektifitas serta efisiensi budidaya tanaman yang menuju kepada meningkatnya nilai ekonomi.

Teknik budidaya yang meliputi pengolahan tanah hingga penerapan teknologi panen sepatutnya selalu dilakukan untuk mencapai tujuan tersebut. Diketahi bahwa terdapat hubungan yang nyata antara umur panen ubikayu dengan hasil fotosintesa berupa karbohidrat. Hasil pati yang dikandung umbi atau lebih dikenal dengan kadar pati akan sangat dipengaruhi oleh umur panennya.

Penelitian tentang umur panen ini mempunyai tujuan diperolehnya umur panen lebih awal yang menghasilkan produksi pati (starch production) tidak berbeda dengan jika dipanen sesuai umur pada umumnya.

Dua varietas ubikayu telah secara resmi dilepas di tahun 2000, kedua ubikayu tersebut berasal dari Thailand, yaitu Rayong 60 setelah evaluasi berganti nama sebagai UJ-3, dan Kasetsart 50 setelah evaluasi berganti nama sebagai UJ-5. Dua varietas baru yang lain secara resmi dilepas di tahun 2001, yaitu adalah Malang 4 dan Malang6. Malang 4 adalah secara penyerbukan terbuka antara Adira4 sebagai induk betina, sedangkan Malang 6 adalah persilangan antara MLG 10.071 dan MLG 10032 sebagai induk betina dan jantan. Ubikayu tersebut mampu menghasilkan lebih dari 10 ton pati per hektar (Kushartoyo dan Puspitorini, 2000).

Di antara komponen teknologi produksi, varietas unggul mempunyai peran penting serta strategis, mengingat varietas unggul terkait dengan potensi hasil per satuan luas, kualitas produk yang menentukan preferensi pengguna, serta potensial mudah diadopsi petani apabila bibitnya tersedia. Sejak tahun 1978 hingga sekarang baru berhasil dilepas 10 varietas unggul dengan karakter beragam seperti pada Tabel 1. Dari pengujian di beberapa lokasi (uji multilokasi), hasil ubi segarnya berkisar antara 20-102 ton/ha, tergantung pada varietas dan kondisi lahannya. Ada yang mempunyai rasa enak (tidak pahit), agak pahit, dan pahit. Berdasarkan kadar HCN dan tingkat rasa pahit, ubikayu dibedakan menjadi tiga kelompok yaitu kelompok pahit dengan kadar $\mathrm{HCN}$ lebih besar dari 100 ppm, agak pahit dengan kadar HCN 50-100 ppm, dan ubikayu tidak pahit dengan kadar HCN lebih kecil dari 50 ppm. Pemanenan sebaiknya dilakukan pada umur optimal yakni 8-12 bulan, tergantung varietasnya. Pemanenan yang melampaui umur optimal akan mempengaruhi mutu karena meningkatnya kadar serat dan menurunnya kadar pati umbi. Penentuan saat panen dapat dilakukan berdasarkan informasi umur panen pada deskripsi varietas. Cara panen ubikayu dapat dilakukan dengan cara mencabut dengan tangan atau dengan bantuan cangkul. Pada tanah yang keras, untuk menghindari tertinggalnya umbi di dalam tanah dan terjadinya luka pada umbi, dapat digunakan alat pengungkit. Menurut Purwadaria (1989), pemanenan dengan alat pengungkit ini relatif lebih efisien (Agroinovasi, 2011)

Secara umum peningkatan umur panen dari 8 ke 10 bulan selalu diikuti oleh peningkatan kadar pati dan tidak ada perbedaan antara panen 10 dan 12 bulan asal panen pada musim yang sama. Panen pada musim kemarau menghasilkan kadar pati yang lebih tinggi. Perbedaan hasil umbi segar dan kadar pati akibat perbedaan waktu tanam dan umur panen juga ditunjukkan oleh penelitian di Lampung. Secara umum varietas UJ5 dan Malang 6 yang ditanam pada bulan 
Pebruari 2006 dan Oktober 2006 lebih baik daripada ditanam pada bulan Juni. Peningkatan umur panen dari8 hingga 11 bulan dapat meningkatkan hasil ubikayu (Subandi, 2009)..iptek tanaman pangan balitkabi.

Penelitian ini diharapkan dapat memecahkan masalah mengenai umur berapa ubikayu harus dipanen agar didapatkan produksi pati tertinggi untuk varietas unggul nasional UJ5 yang digunakan sebagai varietas di beberapa industri tapioka di Indonesia

Tujuan Penelitian adalah menentukan umur panen terbaik untuk produksi pati ubikayu varietas UJ5.

\section{MATERIAL DAN METODE}

Penelitian dilakukan di Kabupaten Blitar Provinsi Jawa Timur pada ketinggian $200 \mathrm{~m}$ di atas permukaan laut. Penelitian dilakukan pada akhir bulan Agustus 2015 hingga Oktober 2016. Bahan yang digunakan adalah batang ubikayu varietas UJ5. Batang ubikayu digunakan untuk penelitain berasal dari batang tanaman umur 8 bulan. Potongan stek yang digunakan adalah batang bagian tengah dengan panjang $1.5 \mathrm{~m}$ dipotong $25 \mathrm{~cm}$ sebagai bahan tanam. Percobaan ini disusun menurut rancangan acak kelompok (RAK) dengan 6 perlakuan dan 3 ulangan. Seluruhnya terdiri dari 18 plot percobaan, masing-masing Plot yang terdiri dari 100 tanaman dan diambil 10 sebagai tanaman sampel. Data yang diperoleh akan dianalisis dengan Varian Test (Anova) 5\% yang akan dilanjutkan dengan Uji BNT 5\% jika nyata. Pengamatan yang dilakukan adalah bobot umbi segar, kadar pati, hasil pati per luasan hektar, index panen (\%), bobot brangkasan. Timbangan yang dipakai untuk menimbang bobot segar umbi per tanaman adalah timbangan per kapasitas $10 \mathrm{~kg}$ yang akan dikonversi ke hektar. Demikian pula hasil pati per hektar diperoleh dari perkalian bobot umbi dan kadar patinya(\%). Kadar pati dianalisis dengan metode Gravimetri. Index Panen dihitung dengan rumus IP = Bobot total tanaman - Bobot Umbi dibagi Bobot Total Tanaman (Sitompul dan Guritno, 1985)

\section{HASIL DAN DISKUSI}

Hasil penelitian yang dianalisis dengan Anova 5\% menunjukkan bahwa pada variabel bobot segar umbi per tanaman didapatkan hasil yang nyata berbeda antar perlakuan. Umur panen 6 hingga 8 bulan menunjukkan hasil sama tetapi tidak lebih baik dibandingkan panen 9 hingga 12 bulan.kg per tanaman hingga $2.91 \mathrm{~kg}$ per tanaman yang dicapai pada umur tanaman 9 hingga 12 bulan. Tetapi untuk panen yang dilakukan pada umur 6 hingga 8 bulan capaian rata-rata bobot segar umbi per tanaman adalah $1.26 \mathrm{~kg}$ per tanaman hingga $1.87 \mathrm{~kg}$ per tanaman. Hasil yang dicapai apabila ubikayu dipanen dengan umur 9-12 bulan nyata $42 \%$ lebih tinggi dibandingkan jika dipanen pada umur 6-8 bulan (BNT 5\%). (Tabel 1)

Waktu panen yang paling baik adalah pada saat kadar pati mencapai tingkat maksimal Menurut Purwadaria (1989) bahwa pemanenan sebaiknya dilakukan pada umur optimal yakni 812 bulan, tergantung varietasnya. Pemanenan yang melampaui umur optimal akan mempengaruhi mutu karena meningkatnya kadar serat dan menurunnya kadar pati umbi. Penentuan saat panen dapat dilakukan berdasarkan informasi umur panen pada deskripsi varietas. Bobot umbi 
meningkat dengan bertambahnya umur panen, sedangkan kadar pati cenderung stabil pada umur 7-9 bulan. Hal ini menunjukan bahwa umur panen ubikayu fleksibel.

Tim Prima Tani (2006) menganjurkan panen pada saat tanaman berumur 8-10 bulan dan dapat $\mathrm{d}$ itunda hingga berumur 12 bulan. Fleksibelitas umur panen tersebut memberi peluang petani melakukan pemanenan pada saat harga jual tinggi. Dalam kurun waktu 5 bulan tersebut (panen 8-12 bulan) dapat dilakukan pemanenan bila harga jual ubikayu naik karena tidak mungkin melakukan penyimpanan ubikayu di gudang penyimpanan seperti halnya tanaman pangan lainnya. Selain itu, pembeli biasanya akan membeli ubikayu dalam bentuk segar yang umurnya tidak lebih dari $2 \times 24$ jam dari saat panen.

Tabel 1. Hasil Bobot Segar Umbi Ubikayu Pada Umur Panen Yang Berbeda

\begin{tabular}{|l|l|l|}
\hline $\begin{array}{c}\text { Umur panen } \\
\text { (BST) }\end{array}$ & \multicolumn{1}{c|}{$\begin{array}{c}\text { Bobot umbi segar } \\
\text { (kegitan-1) }\end{array}$} & \\
\hline - UP 6 & 1.26 & $\mathrm{a}$ \\
\hline - UP 7 & 1.57 & $\mathrm{a}$ \\
\hline - UP 8 & 1.87 & $\mathrm{ab}$ \\
\hline - UP 9 & 2.72 & $\mathrm{c}$ \\
\hline - UP 10 & 2.71 & $\mathrm{c}$ \\
\hline - UP 11 & 2.50 & $\mathrm{bc}$ \\
\hline - UP 12 & 2.91 & $\mathrm{c}$ \\
\hline Standard Deviasi & 0.40 & \\
\hline BNT 5\% & 0.79 & \\
\hline
\end{tabular}

Selain itu bahwa panen tergantung dari umur masing-masing varietas. Varietas ubi kayu yang berumur genjah panen dapat dilakukan pada umur 6-8 bulan, sedangkan varietas berumur dalam dilakukan pada umur 9-12 bulan. Namun secara umum, panen dilakukan pada umur antara 8-12 bulan (Sundari, 2010).

Kandungan pati pada ubi bervariasi antara $80-90 \%$ dari berat kering ubi, tapi sangat cepat mengalami kerusakan, dan faktor inilah yang merupakan salah satu pembatas dalam penggunaan ubi kayu untuk bahan baku industri (Islami,2015).

Pada penelitian ini kadar pati yang dikandung varietas UJ5 jika umbinya dipanen dengan umur berbeda berdasarkan uji Anova 5\% menunjukkan kecenderungan yang sama berkisar antara 25 hingga 29\%. Produksi pati yang tertinggi dicapai pada umur panen 12 bulan (Tabel 2)

Menurut Susilawati (2011) yang penelitian di 2 lokasi, bahwa pada lokasi A, semakin lama umur panen ubi kayu maka semakin tinggi kadar pati ubi kayu yang dihasilkan, sampai dengan umur 10 bulan masih menunjukkan kenaikan kadar pati. Peningkatan kadar pati tersebut disebabkan semakin lama panen ubi kayu, maka semakin banyak granula pati yang terbentuk di dalam umbi. Pada lokasi B, ubi kayu yang berumur panen 8 bulan memiliki kadar pati tertinggi yaitu 18,91\% kemudian menurun seiring dengan bertambahnya umur panen. Penurunan kadar pati ubi kayu diduga akibat meningkatnya komponen-komponen non pati seperti selulosa, hemiselulosa, pektin dan lignin.

Menurut Lakitan (2004), karbohidrat yang terbentuk pada tumbuhan dalam bentuk pati atau amilum. Pembentukan pati diawali dengan meningkatnya aktivitas sintesis pati yang berarti terjadi peningkatan aktivitas enzim ADP-glukose piroposforilase dan UDP glukose piroposforilase Pembentukan pati atau amilum terjadi melalui adenosin difosfoglukosa (ADPG). Pembentukan ADPG berlangsung dengan menggunakan ATP dan glukosa 1-fosfat di kloroplas dan plastid. Transfer fotosintat seperti gliseraldehide 3 fosfat (GAP) dan dihidroksi aseton fosfat (DHAP) tergantung konsentrasi fosfat anorganik di sitoplasma. 
Palupi Puspitorini, Dyah Pitaloka, \& Tri Kurniastuti, 2016. Hasil Ubikayu (Manihot esculenta Crantz) Varietas UJ\% pada Berbagai Umur Panen . Journal Viabel Pertanian. (2016),

10(1) $63-70$

Tabel 2. Kadar Pati dan Produksi Pati Umbi Pada Umur Panen Ubikayu Yang Berbeda

\begin{tabular}{|c|c|c|c|c|}
\hline Plant agesa & $\begin{array}{c}\text { Bobot Segar Umbi } \\
\left(\text { kgtan }^{-1}\right)\end{array}$ & \multicolumn{2}{|c|}{ Starch Content (\%) } & Starch yield (t/ha) \\
\hline - UP 6 & 1.26 & 26.75 & $\mathrm{bc}$ & 6.75 \\
\hline - UP 7 & 1.57 & 29.46 & $\mathrm{c}$ & 9.25 \\
\hline - UP 8 & 1.87 & 28.42 & $\mathrm{c}$ & 10.63 \\
\hline - UP 9 & 2.72 & 25.23 & $\mathrm{ab}$ & 13.73 \\
\hline - UP 10 & 2.71 & 21.25 & $\mathrm{a}$ & 11.51 \\
\hline - UP 11 & 2.50 & 26.75 & $\mathrm{~b}$ & 13.37 \\
\hline - UP 12 & 2.91 & 28.52 & $\mathrm{c}$ & 16.57 \\
\hline Standard Deviasi & 0.40 & 1.92 & & \\
\hline LSD 5\% & 0.79 & 4.03 & & \\
\hline
\end{tabular}

Index panen merupakan hasil umbi dibandingkan bobot total tanaman. Dari hasil penelitian didapatkan bahwa index panen terbesar diperoleh dari ubikayu yang dipanen pada umur 12 Bulan Setelah Tanam (BST) yaitu 57.06\% yang tidak berbeda dengan panen umur 9 dan 10 BST (Tabel3). Index panen yang tinggi menggambarkan hasil tanaman yang efisien dalam menghasilkan umbi pada proses fotosintesisnya. Tanaman yangmenghasilkan panen yang mempunyai index panen tinggi akan memberikan hasil umbi tinggi dibandingkan dengan jika index panennya rendah.

Tabel 3. Index Panen Pada beberapa Umur Panen Ubikayu

\begin{tabular}{|c|c|c|c|c|c|}
\hline $\begin{array}{c}\text { Umur } \\
\text { Panen } \\
\text { (BST) }\end{array}$ & \multicolumn{2}{|c|}{$\begin{array}{c}\text { Bobot Segar Umbi } \\
\text { (g/tanaman) }\end{array}$} & $\begin{array}{c}\text { Bobot Segar } \\
\text { Biomassa } \\
\text { (kg/tanaman) }\end{array}$ & \multicolumn{2}{|c|}{$\begin{array}{c}\text { Index Panen } \\
\text { (\%) }\end{array}$} \\
\hline - UP 6 & 1.26 & a & 1.34 & 48,46 & a \\
\hline
\end{tabular}


Palupi Puspitorini, Dyah Pitaloka, \& Tri Kurniastuti, 2016. Hasil Ubikayu (Manihot esculenta Crantz) Varietas UJ\% pada Berbagai Umur Panen . Journal Viabel Pertanian. (2016),

10(1) $63-70$

\begin{tabular}{|c|c|c|c|c|c|}
\hline - UP 7 & 1.57 & $\mathrm{a}$ & 1.57 & 50,00 & $\mathrm{a}$ \\
\hline - UP 8 & 1.87 & $\mathrm{ab}$ & 1.76 & 51,52 & $\mathrm{a}$ \\
\hline - UP 9 & 2.72 & $\mathrm{c}$ & 2.16 & 55,74 & $\mathrm{~b}$ \\
\hline - UP 10 & 2.71 & $\mathrm{c}$ & 2.39 & 53,14 & $\mathrm{ab}$ \\
\hline - UP 11 & 2.50 & $\mathrm{bc}$ & 2.15 & 49,02 & $\mathrm{a}$ \\
\hline - UP 12 & 2.91 & $\mathrm{c}$ & 2.00 & 57,06 & $\mathrm{~b}$ \\
\hline $\begin{array}{c}\text { Standard } \\
\text { Deviasi }\end{array}$ & 0.40 & & 0.23 & 0.25 & \\
\hline \begin{tabular}{c} 
LSD 5\% \\
\hline
\end{tabular} & 0.79 & & 0.72 & 3.55 & \\
\hline
\end{tabular}

Kesimpulan

Umur panen terbaik ubikayu UJ5 yang ditanam di daerah dengan ketinggian $200 \mathrm{~m}$ dari permukaan laut jika dipanen pada awal musim penghujan adalah umur $9-12$ bulan seteleh tanam (BST). Tetapi untuk index panen terbaik dan hasil pati per hektar tertinggi diperoleh dari ubi kayu yang dipanen pada umur 12 bulan.

\section{Daftar Pustaka}

Annonimous. 2011. Teknologi Budidaya Ubikayu Untuk Mencapai Produksi Optimal. Agroinovasi Edisi 29 Juni - 5 Juli 2011 No.3412 Tahun XLI Badan Litbang Pertanian . hal 1-5

Islami, Titiek.2015. “Ubi Kayu”. Yogyakarta : Graha Ilmu.

Koeshartoyo and Palupi Puspitorini. 2000. Cassava Germplasm Conservation and Crop Improvement in Indonesia. Proceeding of the Seventh Regional Workshop CIAT held in Bangkok Thailand. $P$ 77-86

Subandi dan Zubachtirodin. 2008. Peningkatan efesiensi pupuk N,P,K dan Produktivitas jagung pada lahan kering ultisol kalimantan selatan. Balai penelitian tanaman serealia. Jurnal peneltian tanaman pangan. Vol. 27 no 1 
Palupi Puspitorini, Dyah Pitaloka, \& Tri Kurniastuti, 2016. Hasil Ubikayu (Manihot esculenta Crantz) Varietas UJ\% pada Berbagai Umur Panen . Journal Viabel Pertanian. (2016), 10(1) $63-70$

Sitompul, S.M dan B. Guritno. 1995. Analisis Pertumbuhan Tanaman. Gadjah Mada University Press. Yogyakarta

Sudjadi. 2008. Analisis Produktivitas dan Ekonomis penggunaan Zeolit (ZKK) Pada Usaha Tani Ubi kayu di Kabupaten Tulang Bawang

Susilawati, Siti Nurdjanah dan Sevanadia Putri (2008). Karakteristik Sifat Fisik dan Kimia Ubikayu (Manhot esculenta) berdasarkan Lokasi penanaman dan Umur Panen berbeda. Jurnal Teknologi Industri dan Hasil Pertanian Vol. 13No.2 September 2008. P. 59-72

Tim Prima Tani. 2006. Inovasi Teknologi Unggulan Tanaman Pangan Berbasis Agroekosistem Mendukung Prima Tani. Puslitbangtan Bogor; $40 \mathrm{hlm}$

Titik Sundari, 2010. PETUNJUK TEKNIS Pengenalan Varietas Unggul dan Teknik Budidaya Ubi kayu (Materi Pelatihan Agribisnis bagi KMPH) Balai Penelitian Kacang Kacangan dan Umbi Umbian, Malang Report No. 55.STE.Final. 16 hal 